\title{
The Development of Interactive Multimedia of Arabic Learning
}

\author{
Yogia Prihartini*, Wahyudi Buska \\ Faculty of Islamic Education and Teacher Training \\ Sulthan Thaha Saifuddin State Islamic University \\ Jambi, Indonesia \\ *yogia_prihartini@uinjambi.ac.id
}

\author{
M. Ridha D. S. \\ Faculty of Islamic Law \\ State Islamic Institute (IAIN) \\ Jambi, Indonesia
}

\begin{abstract}
This study aims to produce interactive multimedia learning Arabic. The type of research is research and development with stages consisting of five stages of development, namely analysis, design, development, implementation, and evaluation of learning media. In the analysis phase, we conducted data collection to get the preliminary data needed. Furthermore, the analysis aims to obtain data on how the media concept will be created. The initial design stage has used a storyboard to facilitate the implementation of the design, at the implementation stage, the design is applied to the actual design using the Microsoft PowerPoint program. The final stage is testing conducted by material experts and media experts as well as trials conducted with lecturers and students at the State Islamic Institute of Kerinci. Based on all the stages carried out, a product in the form of interactive multimedia learning Arabic is feasible and effectively used as a learning medium. From the results of field trials getting the final assessment scores obtained for multimedia Arabic learning that had been developed was obtaining an average score of 43.70 in the very good category with an ideal percentage of $87.40 \%$. Based on this assessment, the interactive multimedia of learning Arabic are feasible as a learning medium. The results of this study concluded that the interactive multimedia product of the Arabic language learning that was developed was feasible and effectively applied in learning Arabic at the State Islamic Institute of Kerinci.
\end{abstract} learning

Keywords-development, interactive multimedia, Arabic

\section{INTRODUCTION}

The use of computer multimedia in learning Arabic will be very helpful to the methodology of teaching Arabic so that lecturers can act as facilitators in the learning process [1]. Researchers saw an Arabic learning problem that occurred at IAIN Kerinci on observations on this campus; 1). The use of Arabic learning media has so far been very limited. Lecturers only use textbooks and blackboards as a medium in explaining Arabic learning methods, and massively use grammar methods in lectures. 2). The translation method becomes a favorite method that lecturers consistently use in learning Arabic. 3). The facilities owned by the university have not been optimized for their use to support Arabic learning such as computer laboratories which are only used for learning information technology (ICT). 4). The media used in learning Arabic is still very limited. 5). The speech method is also superior in the learning process and tends to be monotonous, so it does not attract students' interest in learning. In addition, students' ability to understand material varies due to different educational backgrounds.

In learning, lecturers should act more as facilitators and motivators for students. Lecturers invite students to be directly involved in learning so that it creates an impression for students and the memory stored in the student's brain is longterm memory and students can acquire knowledge wherever they seek in their own way. Therefore, the existence of interactive learning multimedia is very important because students can seek and obtain knowledge from various sources through these media [2].

In facing the period of self-quarantine in the atmosphere of the COVID 19 outbreak, Arabic learning must be developed in an online interactive multimedia format, lecturers are required to be more creative in following changes in the learning system from offline learning (face-to-face indoors) to online learning (Virtual learning) [3], [4]. Online learning is an open and distributed learning system using pedagogical tools (educational aids), made possible through the internet and network-based technology to facilitate the formation of learning and knowledge processes through valuable actions and interactions [5].

Online learning media can be understood as media that is equipped with a controller that can be operated by the user [6], so that the user can control and access what the user needs, for example downloading resources for hiwar material in Arabic lectures. The advantages of using online learning media are independent learning and high interactivity, can increase memory levels, provide a more learning experience, with text, audio, video, and animation which are all used to convey information, and also make it easy to convey, update content, downloading, students can also send e-mails to other students, post comments on discussion forums, use chat rooms, to video conference links to communicate directly [7]. 
This research will discuss about the development of learning media products in the form of multimedia learning Arabic, which contains Arabic language material, namely "AtTa'aruf". Multimedia products are made using the Microsoft PowerPoint program by making control buttons, images, text material, audio, and video. In multimedia learning Arabic includes instructions for use of running interactive multimedia programs from starting the program to the end of the program, and contains core competencies, basic competencies, indicators, learning objectives, material, and practice questions [8]. In this learning media program, it contains Arabic language material which is divided into several menus: (1) Mufradat, this menu contains new Arabic vocabulary material which is presented in the form of images and audio which are equipped with an animated display of the emergence of Arabic vocabulary. (2) Istima', This menu contains Arabic conversation material, which is displayed with animated text in the form of audio. (3) Nahwu Wassharf. This menu contains grammar and morphology material in Arabic. which nahwu is the science that discusses grammar and procedures for composing sentences in Arabic. Nahwu is very important and is the main science in learning Arabic besides there is also what is called the Sharf, which is the science of word forms. (4) Qira'ah. This menu contains Arabic reading texts which aim to practice reading Arabic text skills.

This research explores how the development of interactive multimedia Arabic courses at the Department of Arabic Language Education in IAIN Kerinci) in terms of validity, practicality, and product effectiveness. The aim of the development is to get Arabic learning using interactive multimedia that is valid, practical, and effective. In detail, the objectives are: (1) Finding a product in the form of multimedia Arabic learning to improve students' Arabic language mastery skills, (2) Expressing the validity, practicality, and effectiveness of multimedia Arabic learning.

\section{METHODS}

This type of research was Research and Development (R\&D), which is research that is oriented towards developing products. The research developed by stages consisting of five stages of development, namely analysis, design, development, implementation, and evaluation of learning media. This multimedia development procedure follows the development steps of Lee and Owens [9]. The flow or research steps that the researchers did was:

\section{A. Analysis}

The analysis phase contains two steps of activity: a needs assessment and a front-end analysis. Needs analysis is a systematic process of determining goals, identifying differences between actual and desired conditions and determining priorities for action. The analysis steps are needs assessment. For needs analysis, to determine the basic problems is needed in the development of interactive multimedia Arabic learning [10].
The steps in the initial to final analysis consist of: (1) Analyzing students, namely identifying student backgrounds, learning characteristics and conditional skills. Next (2) Analyzing the equipment needed, namely identifying existing supporting technologies [11].

\section{B. Design}

Design, at this stage the activities carried out are: (1) determine the project schedule, (2) determine media specifications, (3) Structuring the content and material, (4) development. At the development stage, products that have been designed are made into physical form. At the development stage, there are components that must be passed, namely: the pre-production stage, the production stage, the post-production stage, and the quality assessment. At this stage, the researcher does the finishing and saves the product results which are then submitted to the media and material experts before the product is used in the field. (5) Implementation. The implementation stage is the stage where the product is tried out [12].

The trial was carried out in several stages, namely: (1) Validation by experts, (2) Conceptual analysis, (3) Revision I, (4) Small group evaluation, (5) Analysis of small group evaluation results, (6) Revision II, (7) Field trials, (8) Analysis of field trial results, (9) Revision III, (10) The last product.

\section{RESULTS AND DISCUSSION}

The development of multimedia learning Arabic uses a procedural model, namely a descriptive model that describes the flow or procedural steps that must be followed to produce certain products [13]. Procedural stages include planning, organizing, implementing, and assessing. Before producing a product, multimedia learning Arabic have been carried out three times in the revision process, including from the supervisor, material experts and media experts, and Arabic language lecturers.

The design process in making multimedia Arabic learning is as follows:

\section{A. Preliminary Research Results}

Based on the results of this preliminary research, the concept of learning media created and developed. From this concept, media that suits need and was easy in the process of making and using it is made by using PowerPoint software. After the media is finished, it is validated by material expert lecturers and instructional media experts as well as Arabic learning design experts.

1) Results of the design of Arabic learning materials: The preparation of learning media requires an analysis of the learning objectives to be achieved and an analysis of the content of the media. The content of this learning media material refers to the applicable curriculum. In this material planning, what is done is to determine competency standards, 
basic competencies, indicators, and main subjects. The subject matter chosen was al-Ta'aruf.

Based on the Arabic learning syllabus, an Arabic learning material design is compiled which will be published in the media to be developed. The media developed contains the main material al-Ta'aruf which is adjusted to the standard of competence in learning Arabic. The media made contains some discussion of the following material:

- Mufradat, which contains some new vocabulary materials which are expected to add to the vocabulary of students' Arabic.

- Istima, contains material about introductions in Arabic.

- Tarkib, contains sentence structure material in Arabic.

- Qira'ah, contains reading text in Arabic.

After determining the main material in this multimedia, then the researchers collected references to the main material al-Ta'aruf. Reference sources used as references include:

- Al-Qowaid Al-Arabiyah Al-Mayassarah by Ahmad Sofwan Nawawi

- Al-Arabiyah Baina Yadaik, by Abdurrahman Ibrahim Fauzan

- Al-Arabiyah Linnasyi'in by Mahmud Ismail Shinni

Then after the material is collected, the next process is to make a storyboard. The results of writing storyboards will be used in the multimedia program production process to be more structured and orderly.

2) Result of software development for Arabic learning media: The results of the development of instructional media software in Arabic subjects in the form of learning media software packaged in Compact Disc (CD). Some of the stages taken in software development are:

a) Analysis: The results of the analysis of the multimedia learning design are divided into two stages, namely the technical specification analysis stage and the work analysis stage. The technical specification analysis stage is for the minimum requirements of a personal computer (PC) to run multimedia learning that is made. This learning multimedia can work in Windows XP, Windows Vista, Windows 7, and Windows 8 operating systems. To be able to display and operate programs on the monitor screen with good quality using a processor with a speed above $2 \mathrm{GHz}$ and $3 \mathrm{~GB}$ of memory.

The software used as the main program in making multimedia is the Microsoft PowerPoint 2013 program, while the supporting program is a Visual Basic (VB) to create and calculate training scores, jet audio and video converter for editing video and sound, office picture manager, paint. And Photoshop CS3 for editing images and Nero 7 for documentation on CD.
The hardware for running this multimedia is a computer unit equipped with a CD Room RW for reading and burning learning media in $\mathrm{CD}$ format, an LCD monitor for displaying programs, a mouse for interaction with the program, and active speakers for accessing sounds in the media. learning.

The hardware for running this multimedia is a computer unit equipped with a CD Room RW for reading and burning learning media in $\mathrm{CD}$ format, an LCD monitor for displaying programs, a mouse for interaction with the program, and active speakers for accessing sounds in the media learning.

The work analysis phase of the program is carried out to find out the work of the learning multimedia that has been made. The interactive learning multimedia work is designed to make it easier for users to learn Arabic subjects, where users can interact in two directions with multimedia via the mouse to get a response from the computer. The results of identification of the work analysis stage of interactive multimedia learning Arabic include:

- When the program is opened and run, it will display the cover page along with the opening audio, which is included in the lower-left corner of the menu button, and in the lower right corner of the close button. If the menu button is clicked, the menus in this multimedia will appear, namely: Instructions, introduction, material, evaluation. As well as the close button to close the application

- In the instructions menu if clicked, will display instructions for using this learning multimedia. If you want to return to the main menu, you can click the home button and the close button to close the application.

- In the introduction menu, if clicked, it will display a menu of core competencies, basic competencies, learning objectives, and indicators. To find out the contents of these menus, click on the menu you want to know.

- When entering the material menu, the materials to be studied with this, multimedia will appear, namely: Istima ', Tarkib, Qira'ah, and Mufradhat. Each menu of the material can be clicked to enter learning materials.

- In each menu of this material to make navigation easier, a next-Prev, home button is also provided in the lower left corner and a close button in the lower right corner. To select other material, select the home button.

- In the evaluation menu, if clicked, it will display a learning evaluation.

- After the program is finished using, to close it use the close button.

b) Program design: After the learning materials have been prepared, the next process to be carried out is program design. The program design is a step in the development phase of this multimedia learning. At this stage, the researcher and 
program development carry out the interface design of this learning multimedia.

The interface design stage is a description of the program structure. The interface or display design is made to make it easier to translate it into a programming language. The interface design is based on the flow chart that was created at the design stage. The following is an interactive multimedia interface design for learning Arabic:

- Cover Design. The front-page design of this learning media consists of a title at the top. In the lower-left corner, there is a menu button to view the main menu options in this multimedia, and in the lower right corner, there is an $\mathrm{X}$ button to exit the program. And if the Menu button on the home page is clicked, it will show the menu options in this media.

- Design instructions page. The design of the instructions page for this media is at the top there is a title, then below it contains instructions for use. There is also a Home button at the bottom left to return to the main menu page and an $\mathrm{X}$ button to exit the program.

- Introductory page design. This Preliminary Page design consists of a title at the very top, then underneath there are buttons for core competencies, basic competencies, learning objectives, and indicators. At the bottom, there is also a Home button on the lower left to return to the main menu page and an $\mathrm{X}$ button to exit the program. This display will appear, namely after we click the introduction menu on the main menu.

- Material page design. For the design of this material page, we can see the menus of the material in this media, namely mufradhat, istima ', tarkib and qira'ah media. Then at the bottom, there is also the Home button at the bottom left to return to the main menu page and the $\mathrm{X}$ button to exit the program.

c) Program implementation: The implementation of the program is the stage of translating or moving the design to its actual appearance in the form of Microsoft PowerPoint 2013 version 15 . The implementation of the interactive multimedia program for learning Arabic is as follows:

- Implementation of Front page (Cover)

- Implementation of Manual Pages

- Implementation of the Competency Page (Home)

- Implementation of Material Pages

\section{B. Inspect of Results by Expert}

After the Arabic learning multimedia product is developed, then the product is evaluated by experts, consisting of material experts and media experts. Then the product is tested on a limited group and a broad group.

1) Expert validation data: Expert validation was carried out by two experts, namely material experts and media experts. Validation is done using a questionnaire. Each questionnaire contains questions, for material experts consisting of 19 questions and for media experts consisting of 14 questions. And for design experts, it consists of 15 questions.

a) Material expert validation: This evaluation aims to determine the depth, clarity, and accuracy of the material chosen by the researcher. The material evaluation was carried out by an Arabic language material expert, there are several suggestions from material experts, namely 1). In the first core competency, material experts suggest directing mastery of Arabic, because this is Arabic learning material, not a religion, 2) al-Ta'aruf sentences need to be adjusted to the language transliteration guidelines, 3) Consistency in writing people's names between audio and text. From the results of the evaluation, according to the Arabic language learning multimedia material expert, after repairs are made, it can be tested or used in research.

b) Media expert validation: This evaluation aims to determine the depth, clarity, and accuracy of the Arabic learning media chosen by the researcher. Media evaluation was carried out by Arabic language media experts, namely Prof. Dr. Aliasar, M.Ed. From the results of the first validation of Arabic learning multimedia, suggestions from the media validator still need to be improved, namely, 1) The clarity of the instructions for using interactive multimedia in Arabic needs to be refined again, 2) The font size used needs improvement, 3) The image shown is still needed improvement, 4) The appearance still needs to be refined so that it is not boring. From the results of the second validation by media experts, it was concluded that Arabic learning media was good and could be tested in research.

\section{2) Results of the trial}

a) Limited group trial: Limited group trials were conducted to determine the quality of Arabic learning multimedia products, data obtained from limited group trials was carried out to revise the product before it was used in the broad group trial. The limited group research was conducted on 27 students of the Faculty of Tarbiyah and Teacher Training at IAIN Kerinci. Students who are the subject of a limited group trial are selected based on observations and data on the learning development of previous students, namely students who have different abilities in Arabic and computer lessons.

The results of the observations at the limited group trial stage showed that in general students still looked stiff in running the Arabic language learning media program. However, after the researcher-led the students to read the manual before running the program, after that the students began to appear to be able to casually run the media program. After reading and following the instructions for use, students began to use the program easily. During this limited group trial process, the researcher got input from the students to add some 
new vocabulary (mufradat) and explain their writing again. From this input is used as input to revise the product further.

The input obtained from media experts and material experts from the results of limited group trials, the researchers make as a reference for revising the products used in broad group trials. Input from media experts and material experts, the researchers can conclude as follows: a). Instructions for using media need to be refined, such as advice from media experts, as students appear confused when running the program when group trials are limited. b). Improved font size and appearance and clarity of the vowels of each sentence. Such as suggestions from media experts to adjust the size and display type of the letters used, as well as suggestions from material experts and student comments that there are still some words that are not clearly legible, either because of writing errors or due to lack of clarity in the appearance of the writing. c) The presentation of mufradat material and the suitability of the mufradat with the theme of the lesson. As suggested by material experts and students during limited group trials.

In a limited group trial, the researcher gave the initial test and the final test to the test subjects who intended to determine the impact of using multimedia Arabic learning that had been made before and after being used in trials.

Based on the results of the initial test and the final test in limited group trials, it was seen that there was an increase in the average learning outcomes of students who were the subject of the trial. The pre-test is given before students use learning media products, while the post-test is carried out after students use learning media. From the results of the two tests, the pretest average score was 60 and the post-test got an average score of 75. From the test results, there was 1 person who did not complete, and 26 students achieved completeness. However, the test results show an increase in student learning outcomes after using instructional media products by 30 points.

b) Broad group trial: This extensive trial was carried out on students of the Faculty of Tarbiyah and Teacher Training, majoring in mathematics education, majoring in physics education, majoring in biology education, and majoring in English education with a total of 50 students. Broad group trials were carried out for 5 lesson meetings. At the first meeting students were given a preliminary test before the Arabic learning media program was used, and the final test was given at the last meeting of the trial of using Arabic learning media.

In conducting the trial, on the first day, apart from conducting the initial test, it was also explained the steps for using Arabic learning media that will be used by displaying instructions for using the program to students. Furthermore, at the learning stage, the Arabic language lecturer uses the Arabic learning multimedia program. During the trial process of using interactive multimedia in learning Arabic, students seemed very enthusiastic about learning Arabic. The students were enthusiastic about practicing the material presented, such as having conversations with friends and being able to introduce themselves using Arabic actively. This indicates that there is an attraction of the media used for students and motivates students to be enthusiastic about learning Arabic.

In the use of interactive media, this is done after the material is delivered and practiced by students. The students are given the opportunity one by one in turn to answer the questions given. After the questions have been worked on, students can see the results of the corrections to the questions they have done, how many are correct, and how many are wrong. During the broad group trial process, researchers haven't only observed the student learning process using interactive Arabic learning media, but also gave students the opportunity to comment and give suggestions on the use of this interactive Arabic learning media. They suggest that the use of learning media like this is more frequently used because it makes them feel happy and excited about learning Arabic instead of just using Arabic textbooks or textbooks.

The pre-test results showed that there were 30 students who did not complete learning and 20 students achieved mastery learning. The average value obtained from the pre-test results was 62.2. Meanwhile, from the results of the post-test scores, there were 5 students who did not achieve mastery learning and 45 students achieved mastery learning. The average value obtained from the post-test results is 79.2. From the results of tests conducted before and after the use of Arabic learning multimedia products, it was found that there was an increase in student learning outcomes after using Arabic learning multimedia products, namely 15 points.

Apart from this, a questionnaire to determine the quality of multimedia learning Arabic products was also given to 50 students of the Faculty of Tarbiyah and Teacher Training, majoring in mathematics education, majoring in physics education, majoring in biology education, and majoring in English education at IAIN Kerinci.

Based on the data analysis technique used, the data obtained from the broad group trial phase in the form of qualitative data were converted into quantitative data. The final score obtained is converted into a qualitative product feasibility level and uses the ideal assessment criteria. Based on the ideal assessment criteria, the quality of Arabic learning multimedia for students of the Faculty of Tarbiyah and Teacher Training at IAIN Kerinci.

Determination of the quality of the learning multimedia that has been produced is based on the classroom trial stage to determine the technical quality of using Arabic learning multimedia. The assessment is carried out by filling in a multimedia learning assessment instrument in the form of a questionnaire. The data obtained were analyzed to determine the quality of the learning multimedia.

The assessment of multimedia learning Arabic is carried out by filling in the assessment instruments provided. The research sheet contains 10 questions along with instructions for filling them out. The results of the assessment in the form of qualitative data were then analyzed to determine the quality of the resulting Arabic learning multimedia. The results of the 
calculation of the ideal assessment category score. The final assessment obtained for multimedia learning Arabic that has been developed is to obtain an average score of 43.70 in the very good category with an idealized presentation of $87.40 \%$

Overall, this learning multimedia are of very good quality and can be used as a medium for learning Arabic for students of the Faculty of Tarbiyah and Teacher Training at IAIN Kerinci. This of course cannot be separated from the input, suggestions, and reviews obtained from media experts, material experts and students.

c) Peer response (Arabic lecturer): In addition to conducting field trials on students of the Faculty of Tarbiyah and Teacher Training at IAIN Kerinci, researchers and developers also have responses and responses from Arabic language teachers regarding multimedia Arabic learning products that have been made. Responses and input from Arabic language lecturers are also important information for researchers in the perfection and usefulness of the products that have been made.

From the responses and input from the Arabic language lecturer, the authors conclude that the use of media in the learning process is very important, because the existence of learning media is expected to accommodate the children's different learning styles of learning. Moreover, in Arabic lessons which are sometimes a frightening specter for students, of course Arabic language lecturers must find ways to attract students' interest and pleasure in learning Arabic so that every material presented can be maximally accepted by student understanding.

The development also received a response about the multimedia learning Arabic that has been made, that the media made is very good when used as learning media in the classroom, so learning does not only depend on textbooks. In addition, the developer also received input and suggestions from Arabic language lecturers, that developers are also expected to be able to make media for other material themes, not only al-ta'aruf material. And hopefully the media that the developer creates can be useful and become a motivation for other Arabic language lecturers to also try to make learning media that is interesting for each subject. Especially the Arabic language lecturer at the Faculty of Tarbiyah and Teacher Training, because the campus facilities already support using computer-based learning media.

3) Discussion of results of the trial: The final score obtained is converted into a qualitative product feasibility level and uses the ideal assessment criteria. Based on the ideal assessment criteria, the multimedia quality of Arabic learning for students at the Faculty of Tarbiyah and Teacher Training at IAIN Kerinci, especially the At-Ta'aruf material of each assessment criteria, can be seen in the Table 1 .
TABLE I. RESULT OF PERCENTAGE OF ELIGIBILITY AND QUALITY OF ASSESSMENT MULTIMEDIA LEARNING ARABIC

\begin{tabular}{|c|c|c|c|}
\hline $\begin{array}{c}\text { Average } \\
\text { Score }\end{array}$ & $\begin{array}{c}\text { Ideal Average } \\
\text { Score }\end{array}$ & $\begin{array}{c}\text { Percentage of } \\
\text { Eligibility }\end{array}$ & Category \\
\hline 43.92 & 50 & 87.85 & Very Good \\
\hline
\end{tabular}

The final product of this development research produces multimedia Arabic learning which includes the subject matter of At-Ta'aruf. Before this multimedia learning was tried out in class, this learning multimedia had gone through several revisions through input from media expert validation and material expert validation.

The determination of the quality of multimedia learning that has been produced is targeted at the test stage of the class to know the quality of multimedia learning techniques that have been created. Assessment is done by filling multimedia assessment instruments in the form of questionnaires. The data obtained is analyzed to determine the multimedia quality of the learning.

The multimedia assessment of Arabic learning that has been made is carried out by filling in the assessment instruments that have been provided in the form of a questionnaire for students which contains 10 questions along with the instructions for filling them. The results of the assessment in the form of qualitative data were then analyzed to determine the quality of the resulting Arabic learning multimedia. The results of the calculation of the ideal assessment category score. The final assessment score obtained for multimedia learning Arabic that has been developed is obtaining an average score of 43.92 in the Very Good category with idealized presentation of $87.85 \%$.

At the multimedia assessment stage, it consists of 10 criteria, namely: a) multimedia can be started easily, b) instructions for running the Arabic learning media program are easy to understand, c) Do you feel happy learning with Arabic learning media, d) media Arabic can help encourage learning Arabic e) Arabic language media can help encourage learning Arabic, especially media can help understand al-Ta'aruf material, f) Arabic media is in accordance with the student's learning speed, g) whether you like the appearance of the color composition and images of the media, $h$ ) the media can help understand a lot of material, i) the media can help encourage the answer to Arabic questions and assignments, $\mathrm{j}$ ) media can help provide new knowledge about computers.

Based on students' assessments from class trials, this Arabic learning multimedia can make it easier and practical for the use of this learning multimedia, so it can help students to increase their interest in learning, especially in Arabic subjects. Overall, this multimedia of learning Arabic is of very good quality and can be used as a learning medium for the subject matter of al-Ta'aruf for students of the Faculty of Tarbiyah and Teacher Training at IAIN Kerinci. 


\section{CONCLUSION}

The results of this study can be concluded as follows: (1) The process of developing interactive multimedia for learning Arabic as a learning medium through five stages of development, namely analysis, design, development, implementation, and testing of instructional media. Through all the stages carried out, it produces an Arabic learning media product that is suitable for use as a learning resource. (2) The products that will be created in this development are Learning media in the form of multimedia Arabic learning which contains Arabic language material, namely "Al-Ta'aruf". This learning media product contains Arabic language material which is divided into several menus, namely: mufradat, Istima', Tarkib, and Qira'ah. This menu contains Arabic reading texts which aim to practice reading Arabic text skills. (3) The feasibility of interactive multimedia products for learning Arabic is declared feasible and can be used in field trials after validation by media experts and material experts. From the results of field trials, the final assessment score obtained for multimedia Arabic learning that has been developed is to obtain an average score of 43.92 in the Very Good category with a percentage of the weakness of $87.85 \%$. Based on this assessment, the Arabic learning multimedia is suitable for use as a learning medium.

\section{ACKNOWLEDGMENT}

I wish to express my sincere gratitude to the conference chair of AES 2020 Putu Indah Rahmawati, SST.Par, M. Bus., $\mathrm{Ph}$. D for providing me an opportunity to present and publish my research in The 5th Asian Education Symposium (AES) 2020 in Bali. I sincerely thank Prof. Dr. Lyn Parker (University of Western Australia), Dr. phil. Dessy Seri Wahyuni (Ganesha University of Education, Indonesia), Prof. Hiroyuki Miyake (University of Kitakyushu, Japan) as keynote speakers. I also thank the Executive Coordinator of UPI Postgraduate School Prof. Dr. Anna Permanasari, M.Si., and all of Committee for their guidance and encouragement in carrying this project work. I also wish to express my gratitude to the officials and other staff members of Indonesia University of Education (UPI) Bandung and Ganesha University of Education who rendered their help during the period of my project work.

\section{REFERENCES}

[1] A.A. Aziz, M.A. Ibrahim, M.H. Shaker, and A.M. Nor, "Teaching Technique of Islamic Studies in Higher Learning Institutions for NonArabic Speakers: Experience of Faculty of Quranic and Sunnah Studies and Tamhidi Centre, Universiti Sains Islam Malaysia.," Univers. J. Educ. Res., vol. 4, no. 4, pp. 755-760, 2016.

[2] D. Laurillard, "Multimedia and the Learner's Experience of Narrative," Comput. Educ., vol. 31, no. 2, pp. 229-242, 1998.

[3] W. Wiana, M.S. Barliana, and A.A. Riyanto, "The Effectiveness of Using Interactive Multimedia Based on Motion Graphic in Concep Mastering Enhancement and Fashion Designing Skill in Digital Format.," Int. J. Emerg. Technol. Learn., vol. 13, no. 2, 2018

[4] A. Hall and J. Herrington, "The Development of Social Presence in Online Arabic Learning Communities," Australas. J. Educ. Technol., vol. 26, no. 7, 2010.

[5] M. Hartnett, A. St George, and J. Dron, "Examining Motivation in Online Distance Learning Environments: Complex, Multifaceted, and Situation-Dependent," Int. Rev. Res. Open Distrib. Learn., vol. 12, no. 6 pp. 20-38, 2011.

[6] R. Rachmadtullah, M.S. Zulela, and M.S. Sumantri, "Computer-Based Interactive Multimedia: A Study on the Effectiveness of Integrative Thematic Learning in Elementary Schools," in Journal of Physics: Conference Series, 2019, vol. 1175, no. 1, p. 12028.

[7] C. Adamczyk, M. Holzer, R. Putz, and M.R. Fischer, "Student Learning Preferences and the Impact of a Multimedia Learning Tool in the Dissection Course at the University of Munich," Ann. AnatomyAnatomischer Anzeiger, vol. 191, no. 4, pp. 339-348, 2009.

[8] N. Tupe, "Multimedia Scenario Based Learning Programme for Enhancing the English Language Efficiency among Primary School Students.," Int. J. Instr., vol. 8, no. 2, pp. 125-138, 2015.

[9] W.W. Lee and D.L. Owens, Multimedia-based instructional design: computer-based training, web-based training, distance broadcast training, performance-based solutions. John Wiley \& Sons, 2004

[10] E. Ekawarna, K.A. Rahman, and F. Firman, "Development of Multimedia Learning Economic Models to Improve Student Learning Outcome,” IOSR J., vol. 6, no. 6, pp. 47-54, 2016.

[11] H. Hamidi and A. Chavoshi, "Analysis of the Essential Factors for the Adoption of Mobile Learning in Higher Education: A Case Study of Students of the University of Technology," Telemat. Informatics, vol. 35, no. 4, pp. 1053-1070, 2018.

[12] Y. Arayici, C.O. Egbu, and S.P. Coates, "Building Information Modelling (BIM) Implementation and Remote Construction Projects: Issues, Challenges, and Critiques.," J. Inf. Technol. Constr., vol. 17, pp. 75-92, 2012.

[13] S. Hartanto, J. Nurkamto, S. Joyoatmojo, and D. Rochsantiningsih, "Model of Android Application-Assisted Arabic Letter Teaching Material Development to Improve Reading Skills and Interests for Beginners," in Proceeding of the International Conference on Teacher Training and Education, 2016, vol. 2, no. 1, pp. 457-465. 